\title{
曲げせん断力を受ける補剛平板の弾性座屈性状と最適補剛剛性 ELASTIC BUCKLING CHARACTERISTICS AND OPTIMUM RIGIDITY OF STIFFENED PLATE UNDER BENDING AND SHEAR STRESS
}

\author{
五十嵐 規矩夫*，柳 下 義 博** \\ Kikuo IKARASHI and Yoshihiro YANAGISHITA
}

\begin{abstract}
From the economical point of view, $\mathrm{H}$-shaped beams which have end stiffeners have been designed in steel frame structures. The purpose of this paper is to reveal the elastic buckling strength of stiffened plates under bending and shear stress. Theoretical analyses using energy method are conducted. As prerequisite for the buckling analysis, web plate element is supposed in consideration characteristic of stiffener. From the analysis, the effect of the stiffeners to the elastic buckling characteristics is inspected and the approximation for optimum rigidity is derived for each boundary condition. In addition, the effective shape of stiffener elements is also investigated with theoretical analyses.
\end{abstract}

Keywords : Stiffened plate, Energy method, Bending inclination, Bending to shear stress ratio, Optimum rigidity 補岡板, エネルギ一法, 曲げ応力勾配, せん断曲げ比, 最適剛比

\section{1. 序}

鋼構造建築物部材は座屈による不安定現象に対して安全であるこ とが設計上の問題である. 特にせいが高い $\mathrm{H}$ 形断面部材では, 幅厚 比の増加に伴うウェブ局部座屈に対する検討が重要な課題となる. 板要素単独で局部座屈を防止することが困難となる場合に対し, ウ エブにスチフナを配置して局部座屈強度を向上させる手法は非常に 効果的である. 適切に配置されたスチフナは経済的にウェブの面外 剛性を増大させ, ウェブ局部座屈強度及び塑性変形性能を向上させ ることが可能となる.

このような背景から, 補剛された板要素に関する検討が古くから 行われている。 まず Timoshenko ${ }^{1}$ は一様圧縮あるいは純曲げ，純せ ん断力を受ける周辺単純支持された補剛平板の弾性座屈耐力をエネ ルギー法により導出している。 また, Klöppel ${ }^{2), ~}{ }^{3}$ は同様の手法を用 いて 1 本あるいは多数の水平スチフナ及び縦スチフナを配置した補 剛平板の弾性座屈耐力を導出しており, 組合せ応力を受ける場合に ついて数多くの図や表を示している.さらに，望月 ${ }^{4), 5)}$ はスチフナ の実用設計式について検討しており，一様曲げおよび圧縮力あるい は純せん断力を受ける補剛平板のスチフナ設計式を提案している. その他にもスチフナの最適剛性について論じられている文献が報告 されており ${ }^{7)}$, これらは日本建築学会の規準 ${ }^{8}$ および指針 ${ }^{9}$ にまとめ られている. しかし, 補岡平板が複合荷重を受ける場合, 基本的な 応力を受ける場合を組み合わせる手法にて座屈耐力を導出している. このように応力を組み合わせることで求められた評価は, 実際の梁
に作用する曲げ応力勾配を考慮し，曲げとせん断が複合的に作用す る場合においても同様に適用可能であるとは言い難い。一方，文献 10)，11)では曲げとせん断の複合荷重を受ける平板の弾性座屈耐力 を評価しており，慣用的に使用されている曲げとせん断の座屈耐力 評価式は平板の座屈耐力を過小評価していることを示している。し たがって, 実際の梁に使用される補剛ウェブの弾性座屈性状を明ら かにするためには曲げとせん断の相互効果を考慮することが非常に 重要である.

また, 従来の補剛平板の座屈解析では大半がスチフナのねじり剛 性による影響を無視しており，スチフナの曲げ剛性のみが考慮され てきた. スチフナの站じり剛性に関する考察は文献 12),13)にて検討 されており，釣合い方程式を用いて補剛平板の近似解を導出してい る。しかし，スチフナの㸚り゙剛性に関するこれらの考察は一様圧 縮力を受ける場合のみを検討するにとどまっている．その他にもス チフナのねじり剛性が補剛平板の座屈耐力に及ぼす影響を考察した

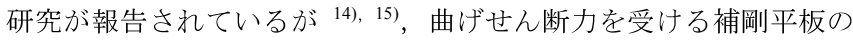
座屈耐力にスチフナの㸚じり剛性が及ぼす影響を考察した文献は著 者の知る限り見受けられない.

梁せいの高い $\mathrm{H}$ 形断面梁の耐震設計梁としての可能性が論じられ, プレートガーダーのように今後さらなるウェブ板に対するスチフナ 補強の必要性が生じることを考慮すれば，曲げせん断力を受ける補 剛平板の座屈挙動に周辺境界条件や外力分布が及ぼす影響を明らか にすることは非常に重要である，さらに，曲げせん断力を受ける補

\footnotetext{
* 東京工業大学大学院理工学研究科建築学専攻

准教授・博士(工学)

Assoc. Prof., Dept. of Architecture and Building Engineering, Tokyo Institute of Technology,

Dr. Eng.

** 東京工業大学大学院理工学研究科建築学専攻 大学院生 Graduate Student, Graduate School, Tokyo Institute of Technology
} 
剛平板の弾性座屈耐力に関寸る有効な指標を提示することができれ ば，高度な補剛平板の座屈設計に大きく貢献するであろう.

以上のような背景を踏まえ, 本論文では曲げとせん断の複合荷重 を受ける補剛平板の弾性座屈耐力を導出し, 補剛平板の弾性座屈性 状について把握する. また, 補剛平板の弾性座屈耐力に周辺境界条 件や曲げ応力勾配が及ぼす影響について考察すると同時に, 補剛平 板の弾性座屈耐力を決定づける主因子について, 各スチフナ剛性が 座屈耐力に及ぼす影響を踏まえて考察する。これらの結果からウェ ブ板の局部座屈補剛に最適なスチフナ剛性について, 既往の研究成 果を参考に簡便な形で近似式を提案し, ウェブ板補剛に効果的なス チフナ形状について明らかにする.

\section{2. 曲げせん断力を受ける補剛平板の弾性座屈解析 \\ 2. 1 補剛板の弾性座屈解析概要}

補剛平板の座屈解析には一般的にエネルギー法 ${ }^{1) \sim 6)}$, 有限帯板法 14)，16)を適用する手法があり，これら以外にも補剛効果を平均化した 直交異方性平板理論 ${ }^{177}$ による手法がある. 本論文におけるスチフナ がウェブの中央に位置する補剛平板の弾性座屈解析では, 比較的精 度が高くかつパラメータを簡便に取り扱える手法であるエネルギー 法を用いて補剛平板の座屈耐力を導出する. まずエネルギー法によ る補剛平板の座屈解析を行う上で, 図 1 に解析モデルを示す. 本論 文で仮定する応力関数を以下の式(2.1), (2.2)に示し, 座屈耐力の導 出に用いる記号およびパラメータを表 1 に示す.

$$
\begin{aligned}
& \sigma(x, y)=\sigma_{w}\left(1-\frac{\beta}{a} x\right)\left(1-\frac{2}{d} y\right) \ldots \ldots \ldots . . . \\
& \tau(x, y)=\bar{\tau}\left[1-\frac{1}{6 \eta}+\frac{y}{\eta d^{2}}(d-y)\right] \cong \bar{\tau}
\end{aligned}
$$

ここで, 補剛平板に作用するせん断応力度分布にはフランジの影響 を考慮している. 本来であればせん断応力度は断面内に放物線分布 を仮定するべきであるが, 本論文では計算の煩雑さを避けるため均 等分布を仮定している. この仮定の妥当性は付録 1 にて検討してお り, せん断応力度分布を均等分布としても十分高い精度の解が得ら れる.

また，本論文における補剛平板の変位関数を式(2.3)に示す.

$$
w(x, y)=\sum_{m} \sum_{n} a_{m n} u_{m} v_{n}
$$

既往の文献において補剛平板の境界条件は単純支持条件として検討 されている場合が大半である. しかし, 鋼構造部材として用いられ る $\mathrm{H}$ 形断面梁を考慮すると, 曲げ応力度が最大となる一端は柱等に 剛結されている場合が多い. また, プレートガーダーのように縦ス チフナと組み合わせた補剛形式をとる場合も見られる. さらに $\mathrm{H}$ 形 断面部材構成板要素の連成座屈を考慮した既往の研究 ${ }^{18)}$, 19)ではウ エブ局部座屈が先行する場合についてウェブのフランジ接合線は固 定支持条件に限りなく等しくなるという知見が示されている. 以上 を踏まえ, 本論文では補剛平板の境界条件を周辺単純支持と周辺固 定支持の 2 条件について検討することとし, 表 2 に示す面外変位関 数を用いて解析を行う.

本論文で考慮するスチフナ剛性は曲げ剛性 $E I_{i}$, ねじり剛性 $G J$, 曲げねじり剛性 $E C_{w}$ である. これらはウェブの曲げ剛性に対して無 次元化された剛比を用いることで取り扱いが容易となり, 以下の式

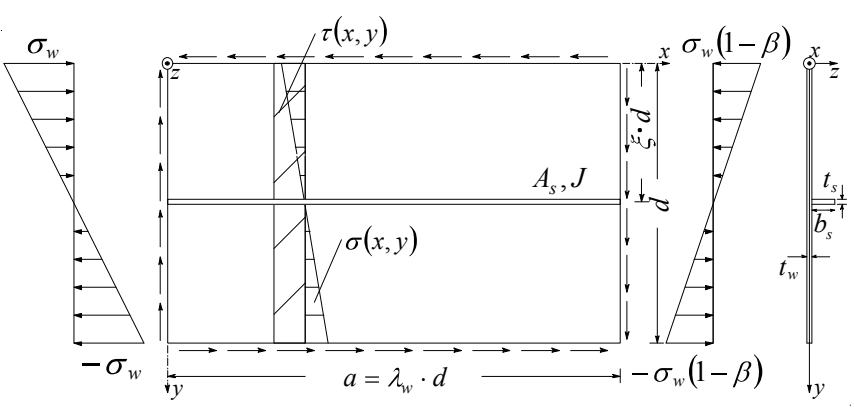

図 1 補剛平板の座屈解析モデル

表 1 記号とパラメータ

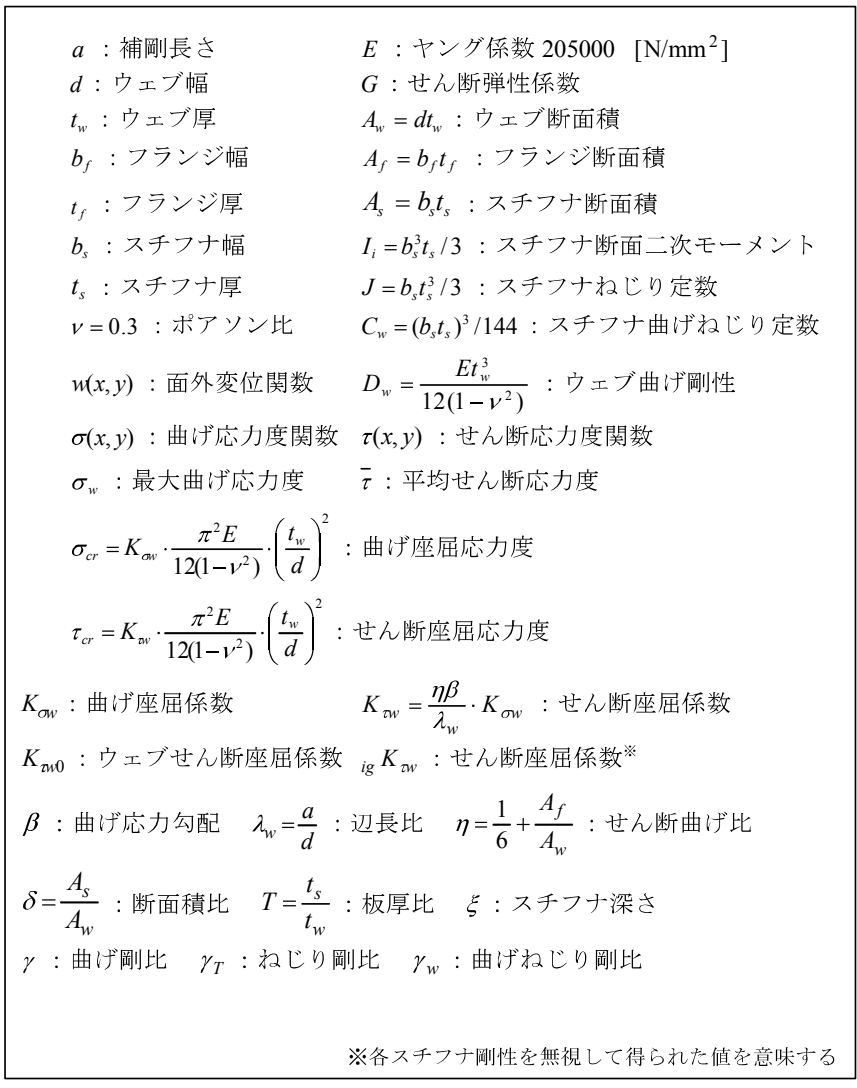

表 2 補剛平板の面外変位関数

\begin{tabular}{|c|c|}
\hline 四辺単純支持 & 四辺固定支持 \\
\hline$u_{m}=\sin \frac{m \pi x}{a}, v_{n}=\sin \frac{n \pi y}{d}$ & $u_{m}=\sin \frac{\pi x}{a} \sin \frac{m \pi x}{a}, v_{n}=\sin \frac{\pi y}{d} \sin \frac{n \pi y}{d}$ \\
\hline
\end{tabular}

(2.4)〜(2.6)のように表すことができる ${ }^{2), 3) . ~}$

$$
\begin{aligned}
& \gamma=\frac{E I_{i}}{D_{w} d}=4\left(1-v^{2}\right) \frac{b_{s}^{3} t_{s}}{d t_{w}^{3}}=4\left(1-v^{2}\right) \frac{\delta^{3}}{T^{2}}\left(\frac{d}{t_{w}}\right)^{2} \\
& \gamma_{T}=\frac{G J}{D_{w} d}=2(1-v) \frac{b_{s} t_{s}^{3}}{d t_{w}^{3}}=2(1-v) \delta T^{2} \\
& \gamma_{w}=\frac{E C_{w}}{D_{w} d^{3}}=\frac{1-v^{2}}{12}\left(\frac{b_{s} t_{s}}{d t_{w}}\right)^{3}=\frac{1-v^{2}}{12} \delta^{3}
\end{aligned}
$$

式(2.4)〜(2.6)はスチフナをウェブの片側に配置した場合について示 している. 現実的なウェブのスチフナ補剛ではバランスを考慮して 
ウェブの両側にスチフナを配置する補剛形式も見られる。しかし， スチフナを両側に配置した場合と片側に配置した場合を比較すると， スチフナ全断面積が一定の場合, 片側配置の方が高い剛比を得るこ とができる，そのため本論文ではスチフナを片側に配置した場合の みを検討対象としている. 本論文では補剛平板の座屈耐力導出に用 いるエネルギー及び仕事を以下の式(2.7)〜(2.12)のように考慮する.

$$
\begin{aligned}
& \begin{aligned}
\Delta U_{w}=\frac{D_{w}}{2} \int_{0}^{a} \int_{0}^{d}\left(\frac{\partial^{2} w}{\partial x^{2}}+\frac{\partial^{2} w}{\partial y^{2}}\right)^{2} \\
-2(1-v)\left[\frac{\partial^{2} w}{\partial x^{2}} \frac{\partial^{2} w}{\partial y^{2}}-\left(\frac{\partial^{2} w}{\partial x \partial y}\right)^{2}\right] d x d y
\end{aligned} \\
& \Delta U_{i}=\frac{1}{2} \gamma D_{w} d \int_{0}^{a}\left(\frac{\partial^{2} w}{\partial x^{2}}\right)_{y=\xi d}^{2} d x \\
& \Delta U_{t}=\frac{1}{2} \int_{0}^{a} \gamma_{T} D_{w} d\left(\frac{\partial^{2} w}{\partial x \partial y}\right)_{y=\xi d}^{2} d x+\frac{1}{2} \int_{0}^{a} \gamma_{w} D_{w} d^{3}\left(\frac{\partial^{3} w}{\partial x^{2} \partial y}\right)_{y=\xi d}^{2} d x \\
& \Delta T_{b}=\frac{t_{w}}{2} \int_{0}^{a} \int_{0}^{d} \sigma(x, y)\left(\frac{\partial w}{\partial x}\right)^{2} d x d y \\
& \Delta T_{s}=-t_{w} \int_{0}^{a} \int_{0}^{d}-\tau(x, y)\left(\frac{\partial w}{\partial x}\right)\left(\frac{\partial w}{\partial y}\right) d x d y \\
& \Delta T_{i}=\frac{1}{2} \int_{0}^{a} A_{s} \sigma(x, \xi d)\left(\frac{\partial w}{\partial x}\right)_{y=\xi d}^{2} d x
\end{aligned}
$$

ここで, $\Delta U_{w}$ : 平板の曲げによるひずみエネルギー, $\Delta U_{i}:$ スチフ ナの曲げによるひずみエネルギー， $\Delta U_{t}$ : スチフナのねじりによる ひずみエネルギーであり, $\Delta T_{b}$ : 曲げ応力度が平板にした仕事, $\Delta T_{s}$ : せん断応力度が平板にした仕事, $\Delta T_{i}$ ：曲げ応力度がスチフナにし た仕事である。なお，本論文が扱うように， $\xi=0.5$ でスチフナがウ エブの中央に位置する補剛平板においては, スチフナが直応力を負 担しないため, 曲げ応力度がスチフナにした仕事 $\Delta T_{i}$ は零である.

以上より, トータルポテンシャルエネルギーの停留原理から以下の 座屈条件式が得られる.

$$
\frac{\partial\left(U_{w}+U_{i}+U_{t}\right)}{\partial a_{m n}}=\frac{\partial\left(T_{b}+T_{s}+T_{i}\right)}{\partial a_{m n}}
$$

式(2.13)は助変数 $a_{m n}$ に関する連立一次方程式となり,一般化固有值 問題として求められた最小固有值が座屈係数 $K_{\text {ow }}$ となる. また, こ
のときの固有べクトルを式(2.3)に代入することで座屈モードが得ら れる. 本来であれば補剛平板の座屈耐力に関寸る考察は座屈応力度 $\sigma_{c r w}, \tau_{c r w}$ を用いるべきであるが，本論文では座屈応力度から幅厚 比の影響を排除した座屈係数 $K_{\text {ow }}$ を用いて種々の検討を行う.

\section{2 解析に用いるパラメータの範囲}

本節では解析を行う上で検討するパラメータの範囲について考察 する．まず，昭和 55 年建設省告示第 1791 号において，曲げを受け る柱または梁の局部座屈に対する補剛長さは，端部から材長の $1 / 10$ または梁せいの 2 倍以上の長さとすることが定められている．これ を踏まえ, 本論文では検討する辺長比 $\lambda_{w}$ 及び曲げ応力勾配 $\beta$ の範 囲を以下とすれば十分対応するものと判断した。

$1.0 \leq \lambda_{w} \leq 3.0$

$0.0 \leq \beta \leq 1.0$

また本論文では，表 1 に示すように曲げとせん断の応力比に関する 重要なパラメータの一つとしてせん断曲げ比 $\eta$ を考慮している。せ ん断曲げ比 $\eta$ は小さな值では曲げの影響が大きく，大きな值ではせ ん断の影響が大きくなることを意味している．この值は文献 10)に て詳細に検討されており，現実的な $\mathrm{H}$ 形断面梁に対する $\eta$ の範囲が 示されている.これを踏まえ, 本論文ではせん断曲げ比 $\eta$ を以下の 範囲にて検討している.

$$
0.5 \leq \eta \leq 2.5
$$

さらに，本論文ではウェブの断面積に対する全スチフナ断面積の 比である断面積比 $\delta$ を考慮する. 断面積比 $\delta$ は式(2.4) (2.6)の全スチ フナ剛性に関係する因子であり，補剛平板の座屈係数を導出する重 要な因子である．本論文では既往の研究 2,3)で検討されている断面 積比の範囲及び経済的なスチフナの断面算定を考慮し $\delta \leq 0.3$ の範囲 にて検討寸る，以上の範囲において，本論文では曲げせん断力を受 ける補剛平板の座屈解析を行い得られた結果を用いて考察を進める。

\section{3. 曲げせん断カを受ける補剛平板の弾性座屈性状}

\section{1 スチフナ剛性が座屈耐カに及ぼす影響}

本節では曲げとせん断の複合荷重を受ける補剛平板の弾性座屈性 状を検討する上で，各スチフナ剛性が補剛平板の弾性座屈耐力に及

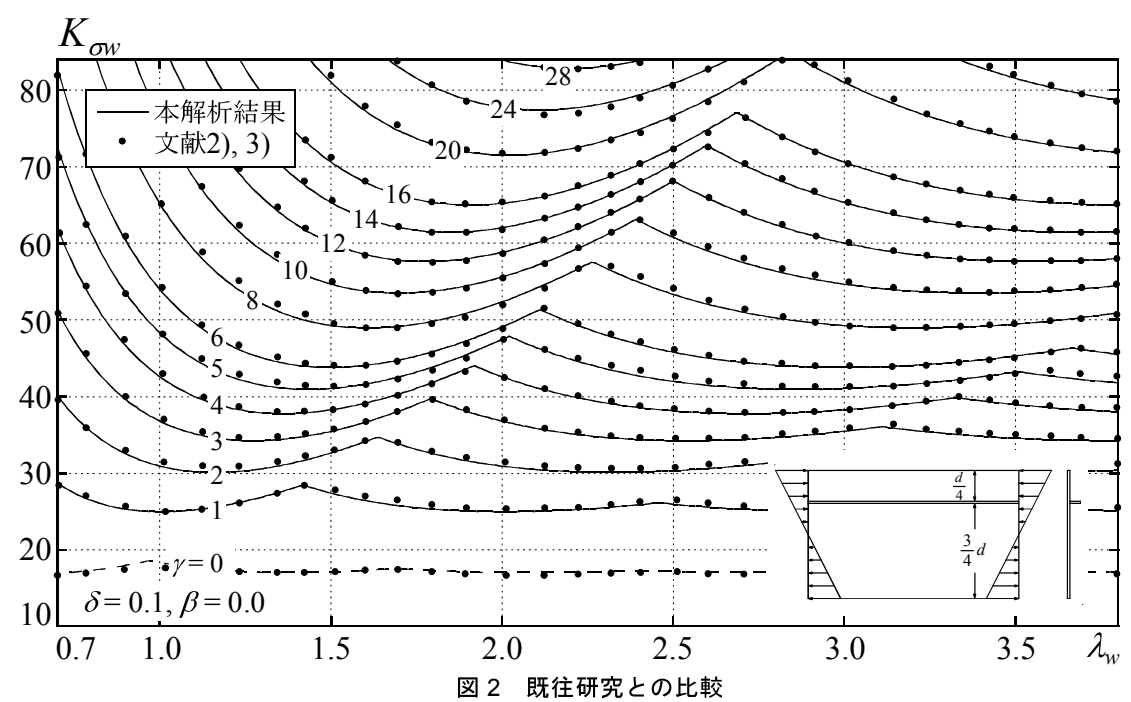

図 2 既往研究との比較

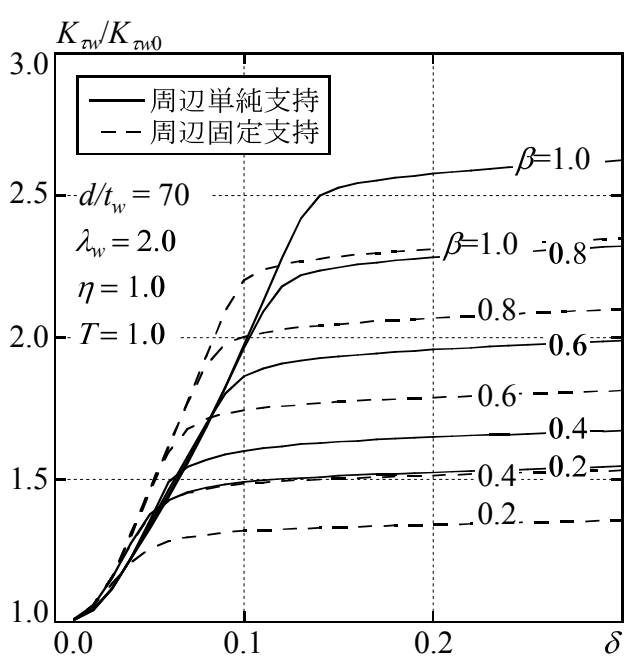

図 3 耐カ上昇率と断面積比の関係 

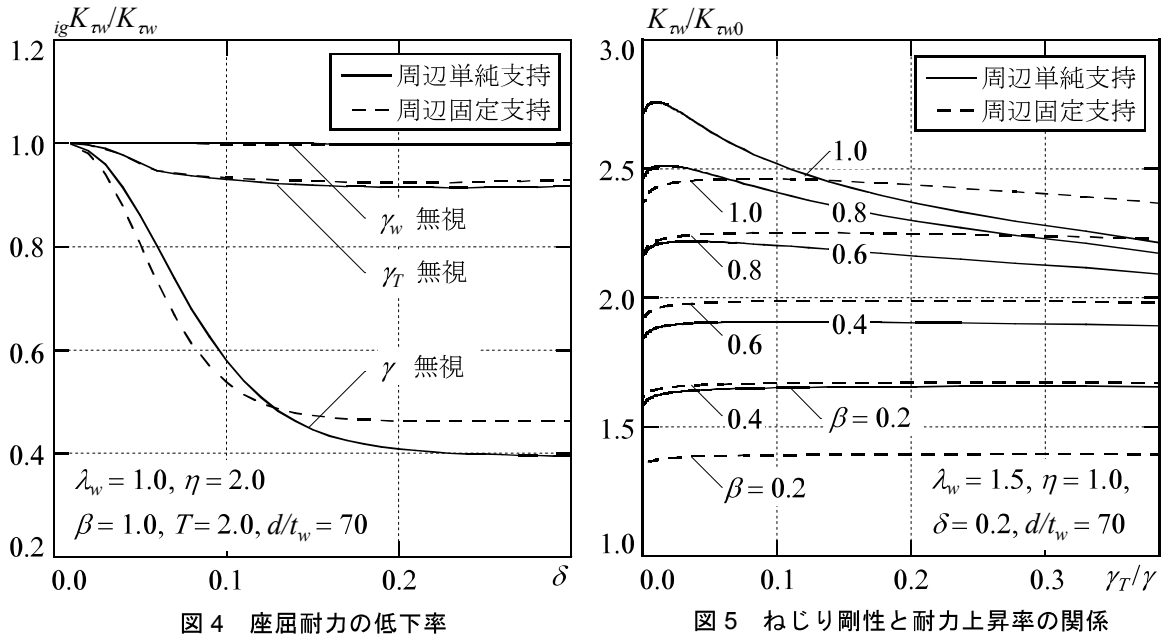

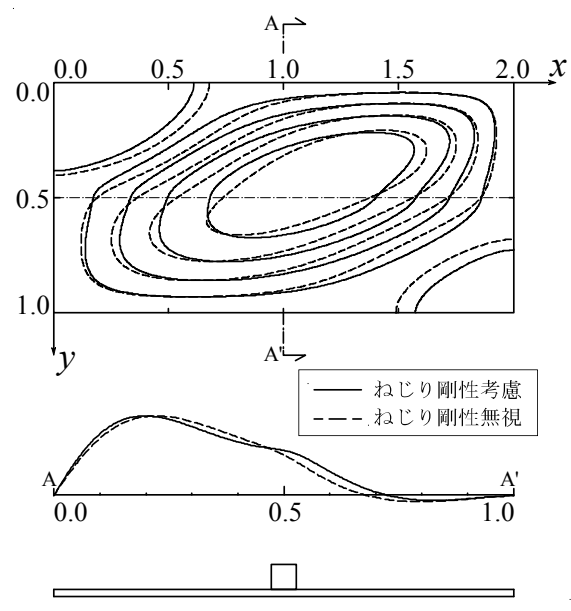

図 6 座屈波形 $\beta=0.5, \eta=2.0, \delta=0.2, \gamma_{T}=4.0$
ぼす影響について考察する. また, 補剛平板の弾性座屈耐力を決定 づける重要なパラメータに関しても併せて考察を進める.

まず，図 2 では本論文の補剛平板の座屈解析の妥当性を検討する ために座屈係数 $K_{\text {ow }}$ と辺長比 $\lambda_{w}$ の関係を示寸. ここでは一例として, スチフナが平板の圧縮縁から $1 / 4$ の深さに位置し, 純曲げ応力を受 ける補剛平板の座屈係数を断面積比 0.1 の場合にて示している. 本 論文の座屈解析結果を実線にて示しており, 既往の研究 ${ }^{2)}$, 3)で得ら れた結果をプロットにて示している. ただし, 既往の研究ではスチ フナのねじり剛性を無視して解を導出しているため, 本論文の座屈 解析では式(2.9)で表されるエネルギーを除外して得られた結果を示 している. スチフナの㸚じり剛性を無視した補剛平板の座屈解析で は, 様々な断面積比 $\delta$ と曲げ剛比 $\gamma$ にいて解を導出することができ る. そのため様々な曲佩剛比にて得られた結果を図中に示している. ただし, 現実的なスチフナ形状を想定する上では曲げ剛比が零をと ることは皆無であるため, 本論文では曲げ剛比が零の場合を点線に て示している. いずれの曲げ剛比においても, 本論文の座屈解析結 果は既往の研究結果 ${ }^{2)}$, 3) と十分対応していることが確認できる.

曲げせん断力を受ける補剛平板の弾性座屈解析で得られる座屈係 数は図 1 に示したような曲げ応力度 $\sigma_{w}$ に対するものである. しか し, 曲げとせん断の相互効果を考慮する場合, 曲げ座屈係数 $K_{\text {ow }}$ を 表 1 中の式のようにせん断座屈係数 $K_{w w}$ に变換して取り扱う方が明 快であると考えられる ${ }^{10)}$. そのため本論文では表 1 中に示すように 曲げ座屈係数 $K_{\text {ow }}$ をせん断座屈係数 $K_{a w}$ に変換して考察を進める. 図 3 に耐力上昇率 $K_{w w} / K_{\text {ww }}$ と断面積比 $\delta$ の関係を示す. 本論文における 耐力上昇率とは補剛平板の座屈係数 $K_{w w}$ を平板の夕の座屈係数 $K_{\mathfrak{w} w 0}$ で基準化した值である. 図より, 断面積比が増加寸ると耐力上昇率 は上昇し, やがて一定值に収束していく.これは式(2.4)〜(2.6)で示 した全スチフナ剛性に断面積比が関係し, 断面積比の増加が全スチ フナ剛性の増加を意味するためであると考えられる：この傾向はあ らゆる曲げ応力勾配において同様であり, 曲げ応力勾配が小さくな るほど耐力上昇率の収束は早くなる. 特に断面積比 0.2 において十 分高い耐力上昇率が得られており, 文献 21)にて示された知見と同 等の結果が得られている. 一方, 点線で示した周辺固定支持条件の 解析結果においても単純支持条件の場合と同様の傾向であると言え る.しかし, 固定支持条件と単純支持条件を比較すると, 曲げ応力
勾配が等しい值において固定支持条件の方が耐力上昇率の収束が早 くなっている.これはウェブに対するフランジの拘束効果や縦スチ フナと組み合わせた補剛形式を用いる場合, 固定支持条件の方がよ り経済的なスチフナ断面算定が可能となることを意味している.

次に, 各スチフナ剛性が補剛平板の弾性座屈耐力に及ぼす影響を 明らかにするために, 全スチフナ剛性を考虑して得られた補剛平板 の座屈係数 $K_{w w}$ に対する各スチフナ剛性を除外して得られた補剛平 板の座屈係数 ${ }_{i g} K_{w}$ の比を座屈耐力の低下率として扱う. その上で図 4 に座屈耐力の低下率 ${ }_{i g} K_{a w} / K_{\text {ww }}$ と断面積比 $\delta$ の関係を示寸. 図 4 で は一例として辺長比 1.0, 曲げ応力勾配 1.0, せん断曲げ比 2.0 の場 合を示す. まず曲げねじり剛比 $\gamma_{w}$ を除外して得られた座屈耐力の低 下率を見ると補剛平板の座屈耐力はほとんど変化していない.これ はスチフナが中実矩形断面の場合では曲げねじり剛性が非常に小さ いためであり，本論文のような補剛形式においては曲げねじり剛比 $\gamma_{w}$ が補剛平板の座屈耐力に及ぼす影響は無視できると言える.これ に対し, 曲げ剛比 $\gamma$ を除外して得られた座屈耐力の低下率は大きく 減少している. また, ねじり剛比 $\gamma_{T}$ を除外して得られた座屈耐力の 低下率も同様に減少する傾向であるが，曲げ剛比の場合と比べてそ の度合いは小さい．また本論文の検討範囲においてはいずれも曲げ 剛比 $\gamma$ を除外して得られた座屈耐力の低下率が最大であり, ねじり 剛比 $\gamma_{T}$ を除外して得られた座屈耐力の低下率が最大となることは なかった．またこの傾向は境界条件によらず，周辺固定支持された 場合においても同様である.

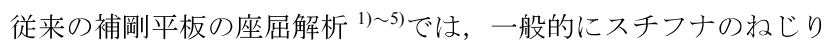
剛性は考慮されず，曲げ剛性のみが考慮されてきた，スチフナのね じり剛性が補剛平板の座屈耐力に及ぼす影響に関しては既にいくら かの考察が知られているが 12)，13)，いずれも特定の例を示すにとど まっている. 図 5 では曲げせん断力を受ける補剛平板の座屈耐力, 座屈性状にスチフナの放じり剛性が及ぼす影響について考察する. 式(2.5)のように衫じり剛比は断面積比 $\delta$ と板厚比 $T$ に依存する. そ のため, スチフナのねじり剛性の影響を考察するためには断面積比 $\delta$ 及び板厚比 $T$ の 2 つのパラメータを用いて考察する心゙きである. しかし, これら 2 つのパラメータを用いると本論文の補剛平板座屈 解析で取り扱うパラメータの煩雑さが増してしまう。曲げ剛比 $\gamma$ が 補剛平板の座屈耐力に大きな影響を及ぼすことや, 既往の研究のよ 


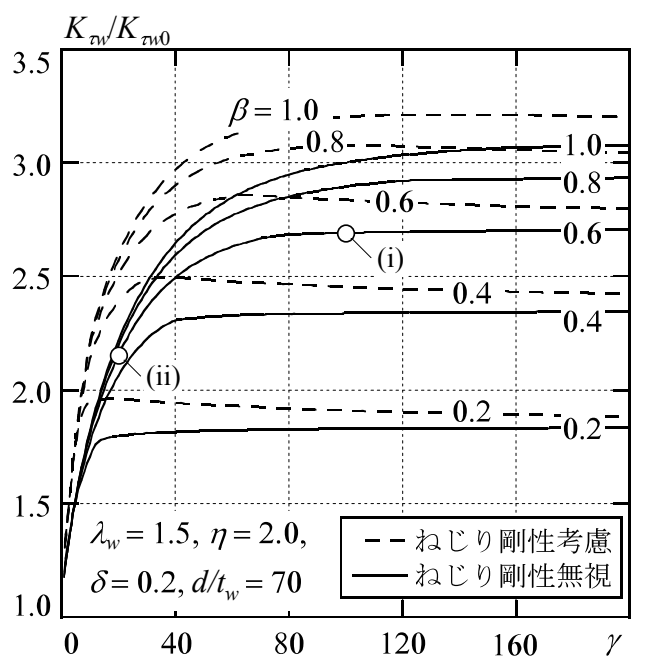

(a) 周辺単純支持

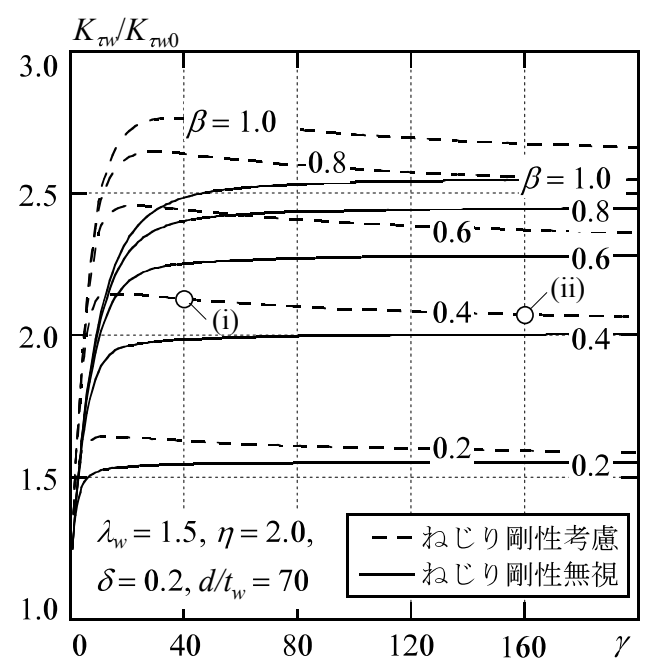

(b) 周辺固定支持
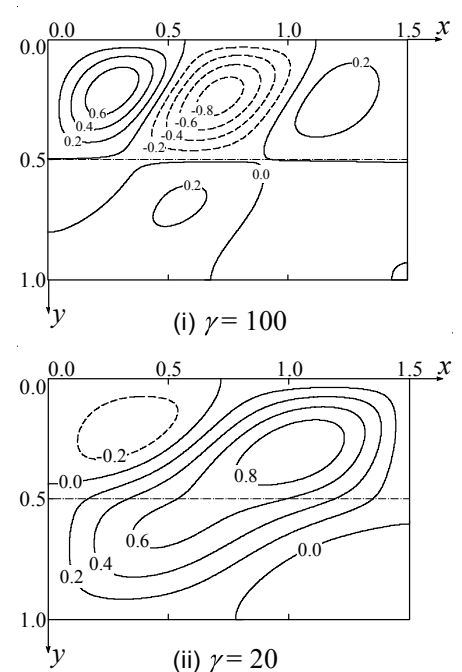

図 8 座屈波形
うに断面積比 $\delta$ と曲げ剛比 $\gamma$ で示した数多くの座屈解析結果との関 係性を考慮すると, 本論文では曲げ剛比とねじり剛比の比 $\gamma_{T} / \gamma$ に 着目寸ることでスチフナのねじり剛性の影響を考察することができ ると判断した。 ここで, $\gamma_{T} / \gamma$ を簡便な形で記すと以下となる.

$$
\frac{\gamma_{T}}{\gamma}=\frac{1}{2(1+v)} \cdot\left(\frac{t_{s}}{b_{s}}\right)^{2}
$$

式(3.1)はスチフナの幅厚比に関するパラメータである.これはスチ フナ形状が変化することでスチフナのねじり剛性と曲げ剛性が同時 に変化するためである， $\gamma_{T} / \gamma$ を大きくするとスチフナのねじり剛 比は増加する一方, 曲げ剛比は減少する. また, $\gamma_{T} / \gamma$ をささく るとねじり剛比は減少する一方, 曲げ岡比は増加寸る. 図 5 は耐力 上昇率 $K_{w w} / K_{w 00}$ と $\gamma_{T} / \gamma$ の関係を示している. 図は断面積比 0.2 の場 合において様々な曲げ応力勾配にて示しており, 線種で境界条件を 区別している. 図より， $\gamma_{T} / \gamma$ が微小な範囲ではどの曲げ応力勾配 においてもねじり剛比を増加させることで耐力上昇率は増加してい く. また曲げ応力勾配が大きな場合では, その後礼じり剛比を増加 させても耐力上昇率の増加は見られず, むしろ減少していくことが 確認できる.これはせん断の影響が大きな平板の補剛にスチフナの ねじり剛性よりも曲げ剛性を高める必要性があることを意味してい る. この傾向は曲げ応力勾配が大きいほど明確であり, 境界条件で 比較すると周辺単純支持の方が顕著である. 一方, 曲げ応力勾配が 小さい場合を見ると， $\gamma_{T} / \gamma$ の值によらず耐力上昇率は概ね一定值 である. 以上より, スチフナのねじり剛性を増加させても補剛平板 の座屈耐力は大きく向上するものではなく, せん断の影響が大きい 場合ではむしろ低下するものと言える.

また, 図6には一例として, ねじり剛性が大きなスチフナを有す る補剛平板の座屈波形を示す．線種にてスチフナのねじり剛比 $\gamma_{T}$ 及び曲げねじり剛比 $\gamma_{w}$ の考慮を区別しており, 補剛平板の中央切断 面及び補剛平板の断面図を併せて示している. ただし, 本論文の座 屈解析より得られる補剛平板の座屈波形は, スチフナの厚さによる 影響が考慮されておらず，スチフナの全剛性が接合線に作用するも のとして解を導出している. まず補剛平板の座屈波形を見ると, ス チフナのねじり剛性の有無に関わらず補剛平板の座屈モードに大き

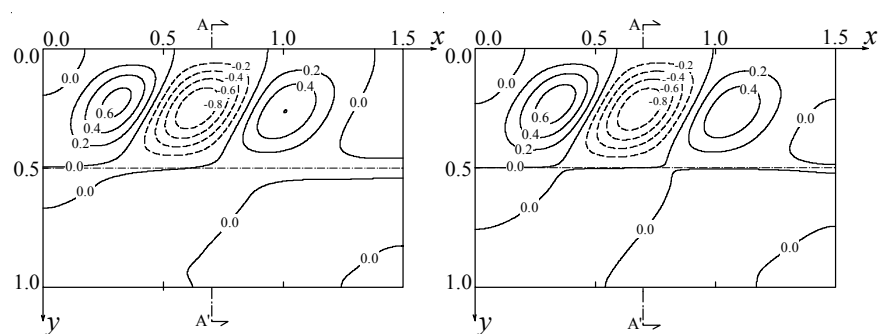

(i) $\gamma=40$

(ii) $\gamma=160$

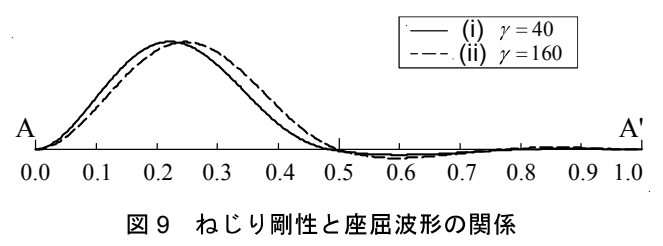

な変化は見られない，辺長比が大きく純曲げ応力を受ける場合にお いては波数の変化が見られる場合も存在するが，本論文のその他検 討範囲においては著しい座屈モードの変化は見受けられない，ただ し, 中央切断面を見ると, スチフナのねじり剛性は接合線のたわみ 角拘束に寄与しており， $\gamma_{T}$ 及び $\gamma_{w}$ を無視した場合と比較するとス チフナ接合線のたわみ角が大きく拘束されている.

このようにスチフナのねじり剛性が補剛平板の座屈耐力及び座屈 モードに大きな影響を及ぼさないことを踏まえ，本論文では補剛平 板の座屈耐力を決定する因子として曲㸃剛比 $\gamma$ に主眼を置き, 曲げ 剛比 $\gamma$ が補剛平板の弾性座屈性状に及ぼす影響について考察する.

図 7 では曲げ剛比 $\gamma$ を横軸にとり, 耐力上昇率 $K_{z w} / K_{\text {w0 }}$ を縦軸に示 している.ここでは断面積比 0.2 の場合において, ねじり剛比 $\gamma_{T}$ 及 び曲げねじり剛比 $\gamma_{w}$ を除外して得られた解析結果を実線にて示し ており，破線にてそれらを考慮した結果を示している．まず， $\gamma_{T}$ 及 び $\gamma_{w}$ を無視した結果を見ると, 曲げ剛比が増加するにつれて耐力上 昇率も増加し, 一定値に収束する。 この傾向は曲げ応力勾配によら ず，曲げ応力勾配が小さいほど耐力上昇率の収束は早くなる．曲げ 剛比の増加はスチフナの曲げ抵抗が増加することを意味しているた め, スチフナのある位置における平板の面外変形が抑制されること になる．そのため十分な曲汭剛比を有する場合ではスチフナ接合線 
が節線となることが考えられる。これは図 8 の座屈波形を考察する ことで非常に明瞭となる. 図 8 は図7(a)中に○で示されている(i), (ii)での座屈波形を示している. 十分大きな曲げ剛比を確保している 座屈モード(i)を見るとスチフナの接合線が節線となっていることが 分かる.そのためスチフナにて仕切られた一方の平板のみに座屈波 形が発生している。 これに対し, 耐力上昇率が十分に収束していな い曲げ剛比の座屈モード(ii)では, スチフナの曲げ抵抗が小さいため 座屈波形が補剛平板全体に及んでいる.

次に図 7 における $\gamma_{T}$ 及び $\gamma_{w}$ を考慮した破線を見ると， $\gamma_{T}$ 及び $\gamma_{w}$ を無視した場合と同様, 曲げ剛比の増加に対して耐力上昇率が増 加する傾向が見られる. また耐力上昇率は $\gamma_{T}$ 及び $\gamma_{w}$ を無視した結 果よりも向上している. しかし, 耐力上昇率が十分に増加した後も 曲げ剛比を増加させると, 耐力上昇率に多少の低下が見られる.こ れはスチフナ接合線が節線となるような座屈モードに対して, 曲げ 剛比は 2 次的な因子となり, 補剛平板の座屈耐力を支配するのはス チフナのねじり剛性となるからである。ここで, 図 9 に図 7(b)中○ の位置(i), (ii)での座屈波形を示す. (i), (ii)はいずれも耐力上昇率が 十分に収束している曲渆比の值における座屈波形を示している. この時スチフナの接合線は節線となっており, 十分な曲げ剛比を確 保していることが分かる. これに対し中央断面図を比較すると, 破 線で示寸(ii) $\gamma=160$ の方が接合線のたわみ角拘束が小さくなってい ることが確認できる。これは(ii)の方が(i)の場合よりもねじり剛性が 小さいためであり, 曲渆比の増加に伴う耐力上昇率の低下はスチ フナのねじり剛性が関係していることが明らかである.

したがって, 曲げ剛比はある值以上としておけば補剛平板の座屈 耐力にほとんど影響を与えないと言える。ただし，スチフナの㱛じ り剛性を考慮して得られた結果では, 必要以上に曲げ剛比を増加さ せると相対的なるじり剛性の減少に伴い座屈耐力が低下する.一方, スチフナのねじり剛性を無視して得られた解析結果は, ねじり剛性 を考慮した場合と比較して座屈耐力の差が小さく適度に安全側な值 が得られるため考察が容易であると言える. 以上より, 以降ではス チフナのねじり剛性を除外して得られた結果を用いて考察を進める.

\section{2 応力状態が座屈耐力に及ぼす影響}

補剛平板に曲げせん断力が作用する場合, 曲げ応力度とせん断応 力度は独立に作用しない. 文献 10)では, 曲げとせん断を分離して
導出した座屈耐力評価手法が平板の座屈耐力を精確に表現すること が不可能であることを指摘している. 本論文で対象と寸る補剛平板 においても曲げとせん断の相互効果を精確に考慮し曲げ応力勾配が 及ぼす影響について考察することは，補剛平板座屈解析の実用的価 值が高まるものと考えられる．本節では曲げとせん断の相互効果が 補剛平板の座屈耐力に及ぼす影響について考察する.

鋼構造設計規準 ${ }^{9)}$ には, 曲げとせん断が作用する周辺単純支持平 板の座屈耐力評価式が示されている. 補剛平板においても同様の手 法により以下の座屈耐力評価式を用いて考察を進める。

$$
\left(\frac{\sigma}{\sigma_{c r}}\right)^{2}+\left(\frac{\tau}{\tau_{c r}}\right)^{2}=1
$$

ここで， $\sigma_{c r}$ : 純曲げ応力を受ける補剛平板の座屈時最大曲げ応力 度, $\sigma$ : 座屈時最大曲げ応力度, $\tau_{c r}$ : 純せん断応力を受ける補剛平 板の座屈時せん断応力度, $\tau$ : 座屈時平均せん断応力度である. た だし，式(3.2)は等曲げ及びせん断を受ける場合の座屈耐力を評価す るものであり，曲げ応力勾配が生じる場合においても同様に適用可 能であるとは限らない. そこで図 10 では本論文の座屈解析結果と式 (3.2)を比較し, 曲げとせん断の相互効果が補剛平板の座屈耐力にお よぼす影響を考察する. 図中に式(3.2)を点線で, 本論文の座屈解析 結果をプロットにて示し，せん断曲げ比の值にてプロット形状を区 別している.いずれの場合においてもプロットは式(3.2)の外側に位 置している.これは式(3.2)の曲げとせん断を分離した座屈耐力評価 手法では補剛平板の座屈耐力を過小評価していることを意味してい る. なお本論文で対象とする検討範囲においては断面積比 0.2 の場 合にて最大で 3 割程度の過小評価となる場合があり，座屈耐力の過 小評価が不経済な設計を招く要因となることを踏まえると，式(3.2) のような慣習的に用いられている座屈耐力評価式は適切であるとは 言い難い. ただしここでは示していないが，辺長比 1.0 の場合，せ ん断曲げ比が大きな值にて若干の過大評価となる場合が見られる.

本論文の座屈解析で得られる座屈係数 $K_{\text {ow }}$ は曲げ応力度とせん断 応力度の比により変化する. 現実的な $\mathrm{H}$ 形断面を想定した場合, 曲 げ応力度とせん断応力度の関係は以下のように表すことができる.

$$
\tau_{c r}=\frac{\beta}{a} \cdot \frac{Z}{A_{w}} \cdot \sigma_{c r}=\frac{\eta \beta}{\lambda_{w}} \sigma_{c r}
$$
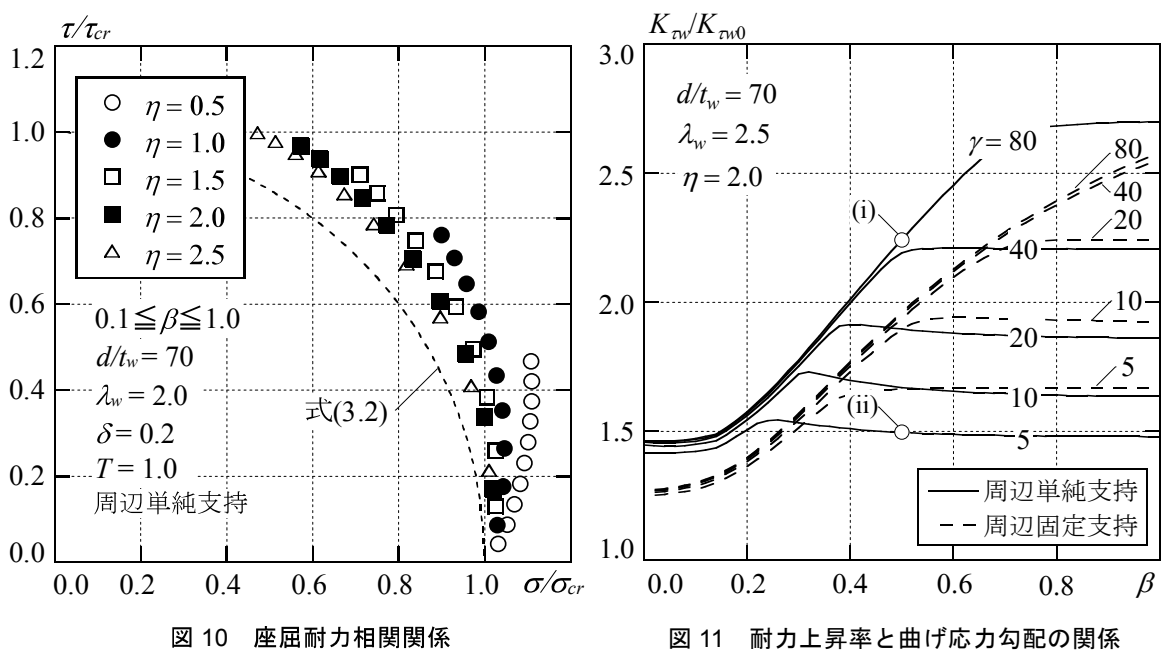

図 11 耐力上昇率と曲げ応力勾配の関係

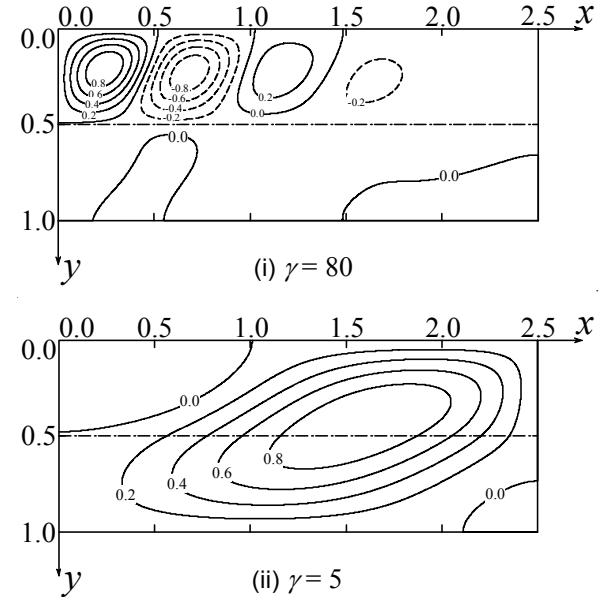

図 12 座屈波形 
式(3.3)から補剛平板に作用する曲げとせん断の応力比には曲げ応力 勾配 $\beta$ 及びせん断曲げ比 $\eta$ が関係し，これらの值が大きくなるほど 連成して生じるせん断力が大きくなる. 図 11 では曲げ応力勾配 $\beta$ と 耐力上昇率 $K_{w w} / K_{w w 0}$ の関係を示寸. 図は辺長比 2.5 , せん断曲げ比 1.0 の場合について示しており, 線種にて境界条件を区別している. ま た曲げ剛比ごとに示すことで曲げ応力勾配と曲げ剛比の関係につい ても考察する. まず曲げ応力勾配が小さい範囲では, 曲げ応力勾配 が増加するとともに耐力上昇率も増加している.この傾向はどの曲 げ剛比においても同様である. しかし, 曲げ応力勾配が大きくなる と, 曲げ剛比が小さいほど耐力上昇率が向上しにくくなることがわ かる.ここで, 図 12 に図 11 中○の位置(i), (ii)での座屈波形を示す. (i)では十分大きな曲げ剛比を有する補剛平板の座屈波形を示してお り，スチフナ接合線が節線となる座屈モードが見られる。一方, (ii) では曲げ剛比が小さい場合を示しており，この時の座屈波形はスチ フナ接合線とともに補剛平板全体に及んでいる。 これより，スチフ ナ接合線が節線となる座屈モードでは, 曲げ応力勾配が大きくなる ほど高い補剛効果が得られると言える.

一方, 図 13 ではせん断曲げ比 $\eta$ を横軸にとり, 耐力上昇率 $K_{w w} / K_{\text {ww }}$ との関係を示す. ここでは辺長比 1.5 , 曲げ応力勾配 1.0 の場合を示 す. 図 11 と同様に, 解析結果を曲げ剛比ごとに示しており, 線種に て境界条件を区別している. 図より, せん断曲げ比が増加するにつ れて耐力上昇率も増加しており, 曲げ剛比が大きいほど高い耐力上 昇率が得られる.この傾向は固定支持条件においても同様である. 図 14 に一例として, 図 13 中○の位置(i), (ii)での座屈波形を示寸. (i)は曲げ剛比が大きな值の座屈波形を示しており, (ii)では曲げ剛比 が小さな值における座屈波形を示している。(i), (ii)を比較すると, (i)では座屈波形がスチフナにて分断されている. 一方, (ii)では座屈 波形が補剛平板全体に及んでいる，これよりスチフナ接合線が節線 となるような座屈モードが得られる場合では, せん断の影響が大き いほど高い補剛効果が得られると言える. そのため固定支持条件に おいて曲け剛比がある程度大きくなると耐力上昇率の大きな向上が 見られないのはスチフナ接合線が節線となるのに十分な曲げ剛比を 確保しているためだと考えられる. 以上より, 適切な曲げ剛比の值 を確保すれば，せん断の影響が大きくなるほど高い補剛効果が得ら
れる．またスチフナ接合線が節線となるために必要な曲げ剛比の值 はせん断の影響が大きくなるほど増加する傾向であると言える。な お，スチフナの衫じり剛性を考慮しても曲げ応力勾配が補剛平板に 及ぼす影響は概ね同様であり，詳細は付録 2 に示す。

\section{4. 曲げせん断カを受ける補剛平板の最適剛比 4. 1 現行の最適剛比との比較}

前章までの解析結果から，曲げせん断力を受ける補剛平板の弾性 座屈耐力の導出に曲げ剛比 $\gamma$ が重要な因子であることを示した．曲 げ剛比はある值以上を確保すれば 2 次的な因子となり，その後は祆 じり剛性が座屈耐力の大小を支配する. そのため, 最適な曲げ剛比 の值を評価することは補剛ウェブの実用的な断面算定をする上で非 常に重要であると言える．また曲げせん断力を受ける補剛平板の最 適剛比が示された文献は著者の知る限り見受けられず, 曲げせん断 力を受ける補剛平板の最適剛比を簡便な形で評価できれば補剛ウェ ブの座屈設計に貢献するものと考えられる. 本節では曲げせん断力 を受ける補剛平板の最適剛比を評価するために, まず最適剛比の考 え方について確認し, 本論文の座屈解析結果との対応を検討する.

補剛平板の最適剛比の実用的な考え方としては, 補剛平板全体の 座屈強度とスチフナによって仕切られた平板の座屈強度を等しくお いた場合の曲げ剛比であるとしている 1) 3)，17)。この時，平板の座 屈強度はスチフナにて仕切られた平板のうち座屈強度が最小となる 圧縮側曲げ応力を受ける平板を周辺単純支持平板としてみなした時 の座屈強度として導出している. ただし, 補剛平板全体の座屈強度 はスチフナのねじり剛性を無視して導出された值が用いられている。 これまで様々な補剛形式及び応力状態について最適剛比の評価式が 提案されており，鋼構造座屈設計指針 ${ }^{9} に$ によめられている.ここ で一例としてスチフナが中央に位置し, 純曲げ応力を受ける補剛平 板の最適剛比を以下に示す.

$$
\gamma^{*}=1.3
$$

純曲げ応力を受ける補剛平板の最適剛比は辺長比によらず一定值で 示される. 図 15 では本論文の座屈解析より得られた最適剛比と式 (4.1)との対応を示す. プロットにて示された本論文の座屈解析結果 と実線にて示された現行の最適剛比を比較すると, 本論文の座屈解

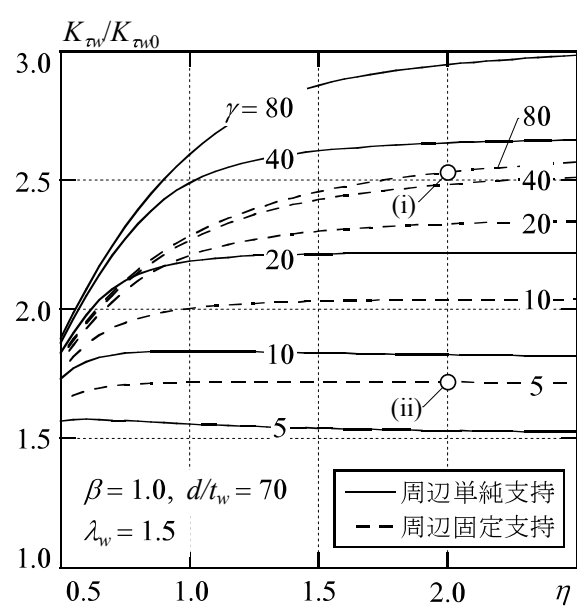

図 13 耐力上昇率とせん断曲げ比の関係

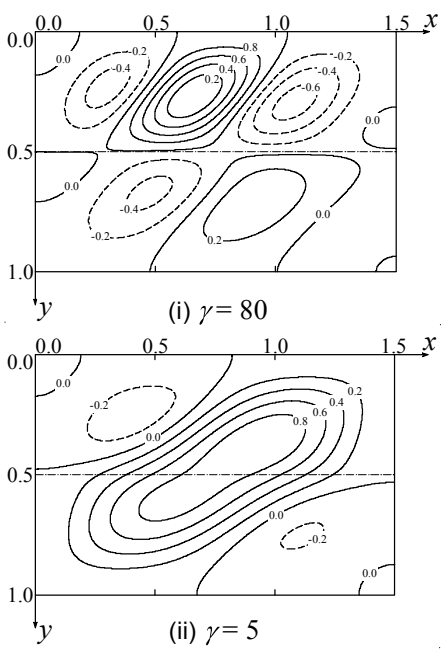

図 14 座屈波形

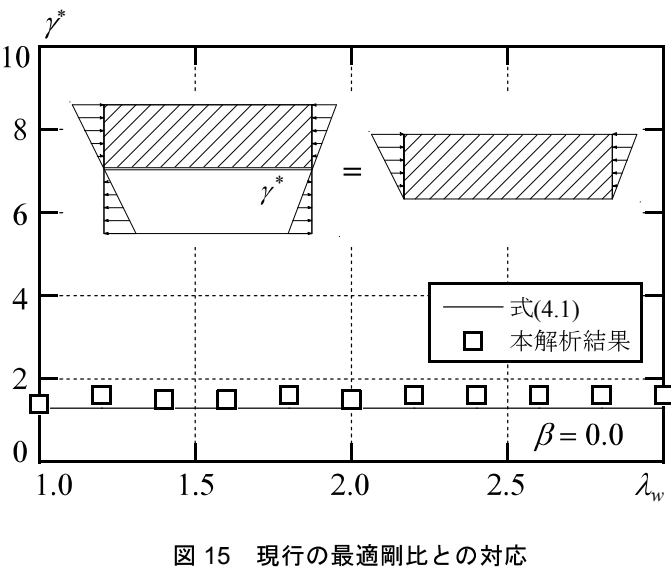


析が若干高い值を示している。これは式(4.1)の導出において危険側 平板の座屈強度に慣習的な評価式を用いており, 本論文よりもスチ フナにより分けられた平板の座屈強度を小さく見積もっているため であると考えられる. なお, 図中に純曲げ応力を受ける補剛平板に 対する危険側平板を斜線にて示す. 本論文の解析結果では危険側平 板の座屈強度に本論文の座屈解析結果を用いて最適剛比を導出して おり，プロットで示した本論文の解析結果を用いる必要があるもの と考える. いずれにおいても本論文の座屈解析より得られた最適剛 比は対応としては十分であると言える.

\section{2 最適剛比近似式の導出}

前節では, 補剛平板の最適剛比について本論文の座屈解析と現行 の最適剛比との対応を確認した. 本節では, 曲げせん断力を受ける 補剛平板の最適剛比について検討し, 簡便な近似式の導出過程につ いて述べる。

これまで示してきたように補剛平板に作用する曲げとせん断の応 力比に関するパラメータとして曲げ応力勾配 $\beta$ とせん断曲げ比 $\eta$ がある. 本論文のような曲げとせん断が複合的に作用する補剛平板 の座屈解析では, 補剛平板の最適剛比を曲げとせん断の応力比を用 いて評価することができれば簡便な近似式の導出が容易になると考
えられる．そこで図 16(a),17(a)では曲げせん断力を受ける補剛平板 の最適剛比を導出するにあたり, 曲げ応力勾配とせん断曲げ比の積 $\eta \beta$ を横軸にとり, 縦軸に最適剛比を示している.ここでは一例とし て辺長比 2.0 の場合を示しており，プロット形状にてスチフナねじ り剛性の有無を区別している．図より，曲げせん断力を受ける補剛 平板の最適剛比 $\gamma^{*}$ は曲げ応力勾配 $\beta$ とせん断曲げ比 $\eta$ の組合せに よらず $\eta \beta$ にて概ね評価することが可能である.最適剛比の簡便な近 似式を導出寸るにあたり，まず $\eta \beta$ が小さい範囲を見ると，最適剛比 は概ね同程度の值をとっている，そのため，この範囲においては最 適剛比を一定值で評価することが妥当であると考えられる。また, $\eta \beta$ がある值以上になると直線的に増加することが分かる. 本論文で はこの範囲において最適剛比を線形的に近似することで簡便な評価 が可能になると判断した。種々の考察より，本論文で得られた最適 剛比の評価式を以下に示す.

a) 周辺単純支持

$$
\gamma^{*}= \begin{cases}\kappa\left[\eta \beta-0.4\left(\lambda_{w}-1.0\right)\right]+1.4 & \eta \beta>0.4\left(\lambda_{w}-1.0\right) \\ 1.4 & \eta \beta \leq 0.4\left(\lambda_{w}-1.0\right)\end{cases}
$$

ただし， $\kappa=30\left(\lambda_{w}-0.5\right)$

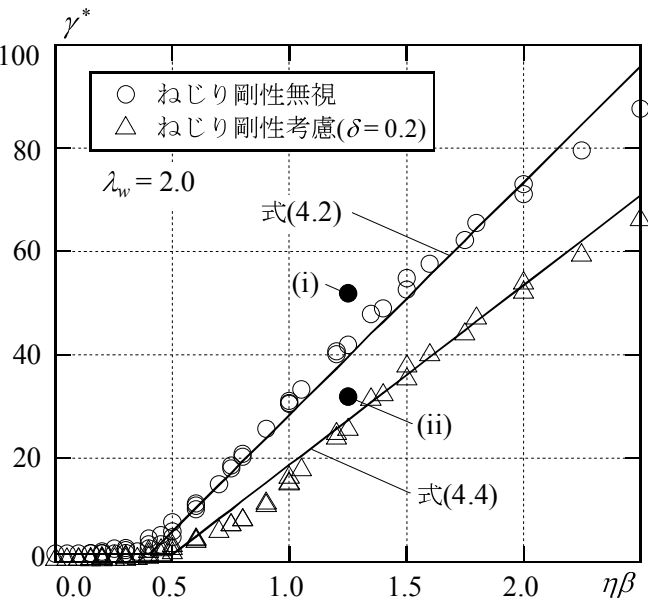

(a) 最適補剛剛比

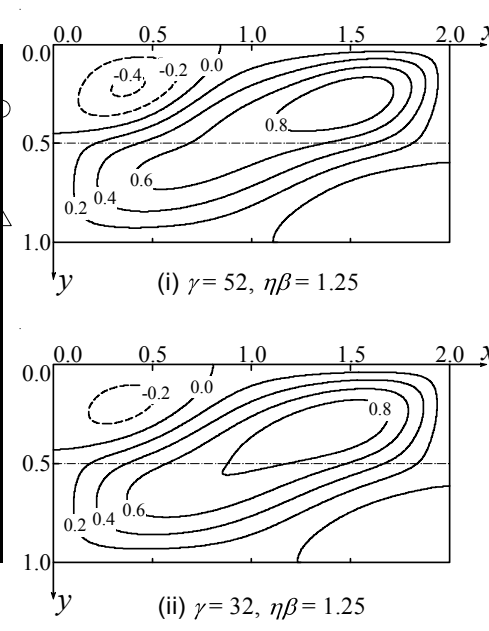

(b) 座屈波形

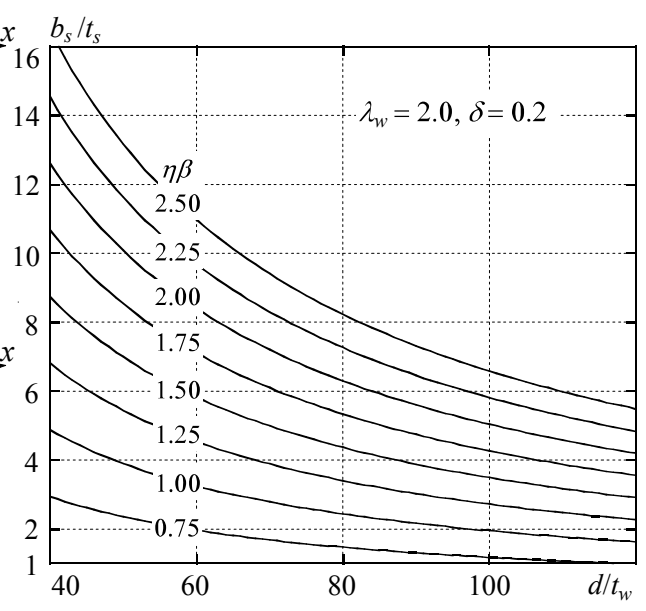

(a) 周辺単純支持

図 16 周辺単純支持

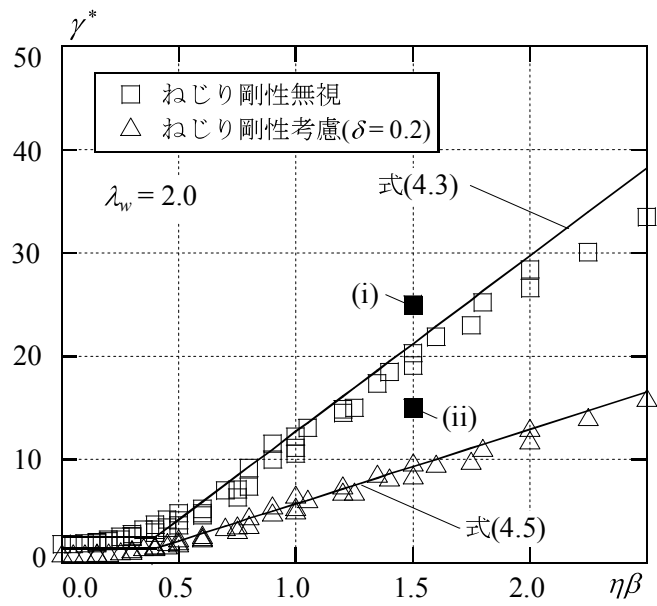

(a) 最適補剛剛比

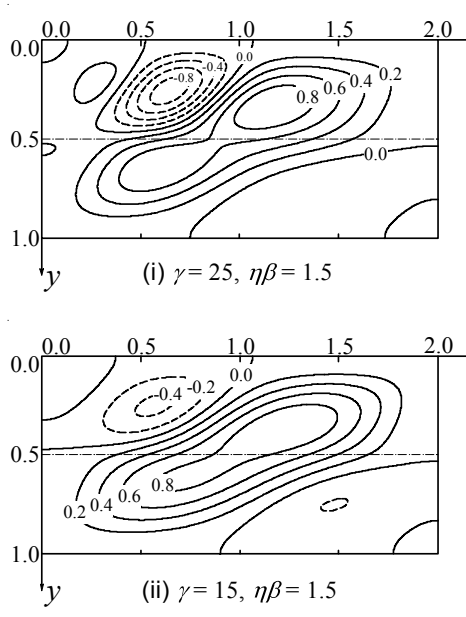

(b) 座屈波形

図 17 周辺固定支持

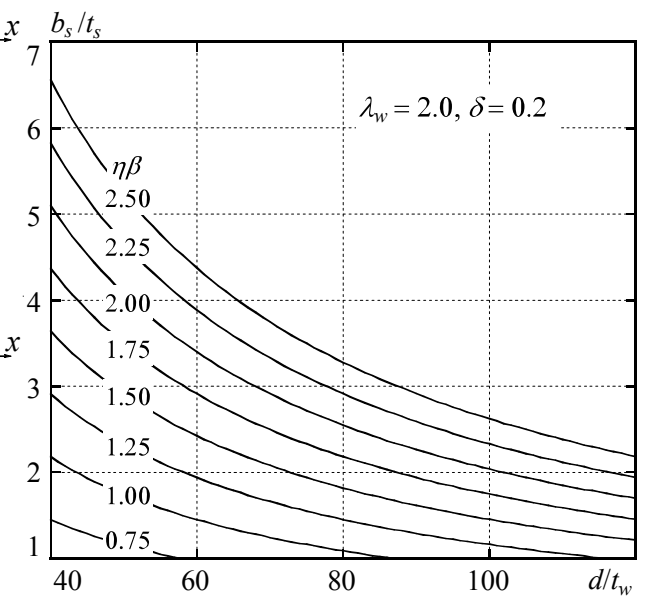

(b) 周辺固定支持

図 18 効果的なスチフナ形状 
b) 周辺固定支持

$$
\gamma^{*}=\left\{\begin{array}{ll}
\kappa\left[\eta \beta-0.4\left(\lambda_{w}-1.0\right)\right]+2.5 & \eta \beta>0.4\left(\lambda_{w}-1.0\right) \\
2.5 & \eta \beta \leq 0.4\left(\lambda_{w}-1.0\right)
\end{array}\right. \text {. }
$$

ただし， $\kappa=-5 \lambda_{w}^{2}+24 \lambda_{w}-11$

なお式(4.2), (4.3)中の係数 $\kappa$ は最小二乗法を用いて導出したもので あり，辺長比による影響も考慮している．図より本論文で検討する 辺長比の範囲において式(4.2), (4.3)が十分な対応を示していること が確認できる.

また図中に示した 最適剛比である.ここでは一例として断面積比 0.2 の場合について 示しており，スチフナのねじり剛性を考慮した場合においても座屈 耐力の観点から導出された補剛平板の最適剛比は $\eta \beta$ にて同様に評 価することが可能であると考えられる．本論文では式(4.2), (4.3)と 同様の手法により得られた最適剛比評価式を以下に示す.

a) 周辺単純支持

$$
\gamma^{*}= \begin{cases}\kappa\left[\eta \beta-0.5\left(\lambda_{w}-1.0\right)\right]+1.4 & \eta \beta>0.5\left(\lambda_{w}-1.0\right) \\ 1.4 & \eta \beta \leq 0.5\left(\lambda_{w}-1.0\right)\end{cases}
$$

ただし， $\kappa=5.2 \lambda_{w}^{2}+14.7 \lambda_{w}-15.5$

b) 周辺固定支持

$$
\gamma^{*}=\left\{\begin{array}{ll}
\kappa\left[\eta \beta-0.4\left(\lambda_{w}-1.0\right)\right]+1.4 & \eta \beta>0.4\left(\lambda_{w}-1.0\right) \\
1.4 & \eta \beta \leq 0.4\left(\lambda_{w}-1.0\right)
\end{array} .\right.
$$

ただし， $\kappa=-2.0 \lambda_{w}^{2}+11.4 \lambda_{w}-7.6$

図 16(a)，17(a)中に式(4.4)，(4.5)を示しており，式(4.2)，(4.3)と比較 すると, いずれにおいても最適剛比の值は小さくなる。これはねじ り剛性を考慮した場合, 補剛平板全体の座屈強度が上昇するのに対 して危険側平板の座屈強度は同じ值を用いているからである。いず れにおいても本論文で検討する辺長比の範囲において式(4.4), (4.5) は十分な対応であると言える。

ただし, 本論文で示した最適剛比はスチフナ接合線が節線となる ことを保証してはいない。これは図 16(b)，17(b)に示寸座屈波形を 見ると明らかとなる. 図 16(b), 17(b)は図 16(a), 17(a)中に黒塗りで 示した点における座屈波形を示している. (i)では本論文で導出した 最適剛比式(4.2), (4.3)を満足する場合の座屈波形を, (ii)では式(4.2), (4.3)を満足しない場合における座屈波形を示しており, (i) と(ii)を比 較すると座屈波形が大きく変化していないことが確認できる。これ は本論文で導出した最適剛比はあくまで座屈耐力の観点から導出し たものであることを意味している．このため四辺単純支持条件とし て導出した危険側平板の座屈耐力はスチフナ接合線が節線となるた めの座屈耐力に対して小さく見積もっている可能性があり, 最適剛 比を満足してもスチフナ接合線が完全な節線とはならない場合があ ると考えられる.

\section{3 効果的なスチフナ形状}

本節では曲げせん断力を受ける補剛平板の効果的なスチフナ形状 について前節までの考察結果を踏まえて検討を加える. 補剛ウェブ のスチフナ設計では最適剛比 $\gamma^{*}$ を満足するようにスチフナ形状を 選定し, スチフナにて仕切られたパネルの中で最も危険側となるパ ネルに対して座屈検定を行う。しかし, 曲げ剛比はウェブの面外曲 げ剛性に対するスチフナの曲げ剛性の比であるため, 最適剛比が一
定の場合でも補剛対象とするウェブ形状によって最適剛比を満足す るスチフナ形状は変化する．そこで本論文では効果的なスチフナ形 状とウェブ形状との関係を考察する上で，曲げ剛比を以下の式に示 寸形で書き換える。

$$
\gamma=4\left(1-v^{2}\right) \delta^{2} \frac{b_{s}}{t_{s}} \frac{b_{w}}{t_{w}}
$$

式(4.6)より断面積比が一定の場合，ウェブ形状とスチフナ形状の関 係が明膫となることがわかる. 図 18 は式(4.2), (4.3)に示寸最適剛比 を与えるスチフナ形状とウェブ形状の関係を示している。ここでは 十分高い耐力上昇率が得られる断面積比である $\delta=0.2$ の場合につい て様々な $\eta \beta$ にて示している.補剛対象とする梁断面から算定したせ ん断曲げ比 $\eta$ と補剛長さに対応するように算定した曲げ応力勾配 $\beta$ との積 $\eta \beta$ を算定し, 図からウェブ幅厚比に対応するスチフナ幅 厚比以上の值を用いることで効果的なスチフナ形状が算定可能とな る. 図は一例として辺長比 2.0 の場合を示しているが，その他の辺 長比においても式(4.2) (4.5)より得られた最適剛比と式(4.6)を用い ることでウェブ形状とスチフナ形状の関係を得ることができる．ま た，図 1 に示すスチフナが両側に配置されている場合においても同 様にウェブとスチフナ形状の関係を導出することができる.ただし， スチフナが両側に配置されている場合では，式(4.6)における係数 4 を 2 に書き換えた形で用いる必要がある.

\section{5. 結}

本論文では曲げせん断力を受ける補剛平板の弾性座屈耐力を導出 し, 補剛平板の弾性座屈性状にスチフナ剛性が及ぼす影響について 考察した. また, 補剛平板の弾性座屈耐力に外力分布, 境界条件が 及ぼす影響について考察した。また, 補剛平板の座屈耐力を決定づ ける主因子が曲げ剛比 $\gamma$ であることを示し，曲げせん断力を受ける 補剛平板に最適な曲げ剛性比 $\gamma^{*}$ を簡便な形の評価式で提案した。さ らに最適剛比を満足するウェブ形状とスチフナ形状との関係につい て考察を加えた. 本論文で得られた知見を以下にまとめて示す.

1）本論文では周辺単純支持に加えこれまで十分に明らかにされて いない周辺固定支持の境界条件について扱い，その弾性座屈性 状を明らかにした，その上で補剛平板の座屈耐力が十分向上す るために必要な断面積比の值は，境界条件で比較した場合，単 純支持条件よりも固定支持条件の方が小さく見積もることがで きる.

2）曲げせん断力を受ける補剛平板の弾性座屈耐力を決定づける主 因子は曲げ岡比である．曲げ剛比をある值以上まで増加させる ことでスチフナ接合線が節線となる座屈モードが得られるが, それ以降では 2 次的なものとなり, 衩じり剛性が座屈耐力の大 小を左右する。

3） スチフナねじり剛性は接合線のたわみ角拘束に寄与するもので あるが，中実矩形断面による補剛形式においてはねじり剛性が 補剛平板の座屈耐力を大きく向上させるものとは考え難い.

4）曲げせん断力を受ける補剛平板の弾性座屈耐力は曲げとせん断 の相互効果を考慮することで効率的なスチフナ形状が算定可能 となる．また，スチフナ接合線が節線となるための曲げ剛比は せん断の影響が大きいものほど増加する。

5)実用的な補剛平板の最適剛比は補剛平板全体の座屈耐力とスチ 
フナにより分けられた平板の座屈耐力を等しいとしたときの曲 げ剛比であり, 曲げせん断力を受ける補剛平板においてはせん 断曲げ比と曲げ応力勾配の積を用いることで評価が可能である. 辺長比を考慮した最適剛比を式(4.2)〜 (4.5)に示した.

6）補剛スチフナの最適形状は, 曲げの影響が大きい断面ではねじ り剛性の高いものが，せん断の影響が大きい断面では曲げ剛性 の高いものがウェブの補剛に効果的であり, ウェブ幅厚比が大 きくなるほど最適剛比を満足するスチフナ幅厚比は小さくなる.

\section{参考文献}

1) Stephen P. Timoshenko \& James M. Gere : Theory of Elastic Stability, McGraw-Hill Book Company, 1963.

2) Klöppel E.und Scheer J. : BEULWERTE ausgesteifter Rechteck platten, Wilhelm Ernst \& Sohn, 1960.

3) Klöppel E.und Möller K.H. : BEULWERTE ausgesteifter Rechteck platten, II Band, Wilhelm Ernst \& Sohn, 1968.

4) 望月力男: 矩形ウエブ板縦方向スチフナの研究, 日本建築学会論文集, 第 43 号, pp.25-31，1951.7.

5) 望月力男：剪断を受ける矩形ウエブ板縦方向スチフナの実用算定式につ いて，日本建築学会論文報告集，第 75 号，pp.25-30，1962.8.

6) 山平喜一郎：エネルギー法による補剛板の座屈解析プログラム, 住友重 機機械技報，Vol.31， No.91，1983.4

7) R. Narayanan : Plated Structures, Applied Science Publishers, 1983

8) 日本建築学会 : 鋼構造設計規準, 2005.5.

9) 日本建築学会 : 鋼構造座屈設計指針, 2009.11 .

10) 五十嵐規矩夫 : 不均等曲げせん断力を受ける $\mathrm{H}$ 形鋼ウェブの座屈耐力評 価一周辺単純支持平板としての弾性座屈耐力評価一, 日本建築学会構造 系論文集，第 565 号，pp.135-141，2003.3.

11) 五十嵐規矩夫，鈴木㻟也：曲げせん断および軸力を受ける平板の弾性座 屈耐力評価法, 日本建築学会構造系論文集, 第 573 号, pp.209-216, 2003.11.

12）楠田忠雄: 圧縮力を受ける補強板の塑性座屈について一第 1 報 軸対称型 防撓材を有する場合一, 造船協会論文集, 第 105 号, pp.137-146, 1959.7.

13）楠田忠雄: 圧縮力を受ける補強板の塑性座屈について一第 2 報 非対称型 防撓材を有する場合一, 造船協会論文集, 第 106 号, pp.171-179, 1960.6.

14) 宇佐美勉：補剛材つき板の弾性ならびに非弾性圧縮座屈強度, 土木学会 論文報告集，第 105 号，pp.13-28，1974.8.

15) 大村裕, 吉浪康行: 補剛板の座屈に及ぼす補剛材の偏心とねじれ剛性の 影響について，土木学会論文報告集，第 267 号，pp.9-15，1977.11.

16) 長谷川彰夫, 太田孝二, 西野文雄 : 補剛された板要素の座屈強度に関す る2・3 の考察, 土木学会論文報告集, 第 232 号, pp.1-15, 1974.12

17) 宇佐美勉, 福本唀士：圧縮力と曲げモーメントを受ける補剛材つき板の 座屈強度と設計，土木学会論文報告集，第 247 号，pp.35-49，1976.3.

18）五十嵐規矩夫, 鈴木玩也 : 逆対称曲げせん断力を受けるウェブ平板の弾 性座屈耐力に及ぼす境界条件の影響, 日本建築学会構造系論文集, 第 571 号，pp.145-152，2003.9.

19) 五十嵐規矩夫, 王蓞 : 曲げせん断力及び軸力を受ける H 形断面構成板要 素の弾性座屈耐力算定法, 日本建築学会構造系論文集, 第 613 号, pp.137-146, 2007.3.

20）五十嵐規矩夫，鈴木玩也，王蓞：逆対称曲げせん断力および軸力を受け
るウェブ平板の弾性座屈耐力に与えるフランジ据り剛性の影響, 日本建 築学会構造系論文集, 第 588 号, pp.173-179, 2005.2.

21）五十嵐規矩夫，柳下義博：不均等曲げせん断力を受ける中立軸補剛平板 の弾性座屈耐力, 鋼構造年次論文報告集, pp.353-358, 2013.11 .

\section{付録 1 補剛平板に作用するせん断応力度分布と解の収束性}

節 2.1 で述べたように，本論文では補剛平板に作用するせん断応力度分布 を均等分布としている。本来であればせん断応力度分布は断面内に放物線分 布を仮定するべきであるが，せん断応力度分布が解に及ぼす影響は小さい． 付図 1 はせん断応力度分布の違いによる解析結果の一例を示しており，プロ ットで示したように均等分布としても得られる解は十分精確であると言える 変位関数を仮定する際, 波数 $M, N$ を任意に定めることができる. 波数を少 なくすることで解析の計算過程を簡便にすることができる一方，波数が多い ほど得られる結果は精解に近づく，付図 2 は波数が解の精度に与える影響を 示している.プロット形状で断面積比の值を区別しており，断面積比におい ても収束の度合いは同様であることがわかる，以上より，本論文では変位関 数の波数を $M, N=20$ として十分妥当な解が求められると判断した。

\section{付録 2 曲げ応カ勾配と耐カ上昇率の関係にスチフナのねじり剛性が及ぼす 影響}

節 3.2 ではスチフナのねじり剛性を無視して得られた解析結果を用いて考 察を進めた．実際の補剛平板にはスチフナのねじり剛性が影響することを踏 まえ，ねじり剛性を考慮した場合における結果を以下の付図 3 に示寸.
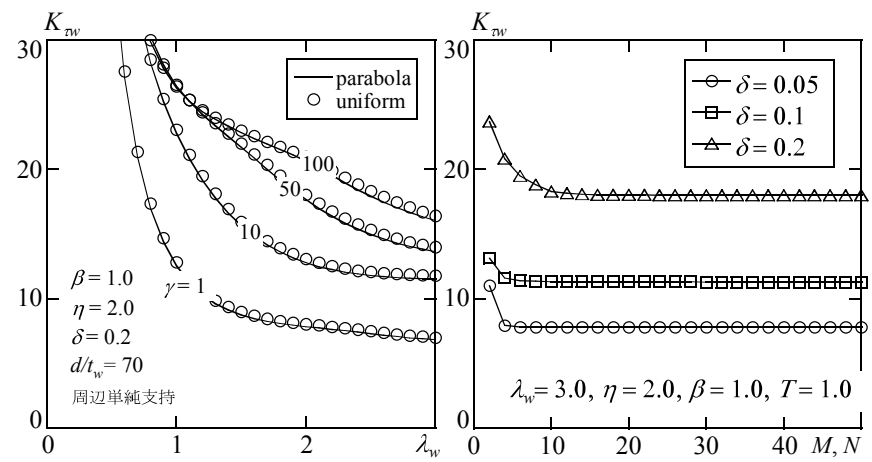

付図 1 せん断応力度分布の影響 付図 2 解の収束性, $M=N$

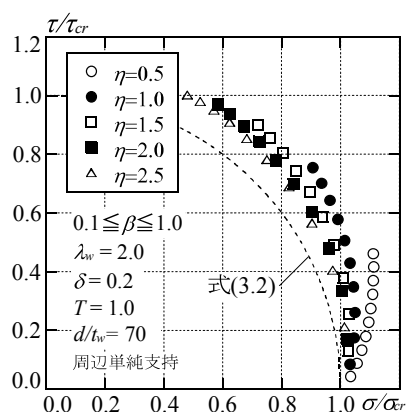

(a) 座屈耐力相関関係

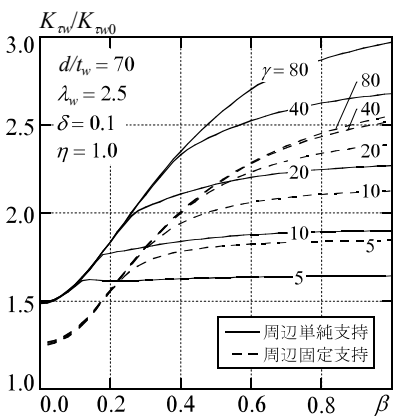

(b) 耐力上昇率と曲げ応力勾配の関係
付図 3 曲げ応力勾配と耐力上昇率の関係に及ぼすねじり剛性の影響 


\title{
ELASTIC BUCKLING CHARACTERISTICS AND OPTIMUM RIGIDITY OF STIFFENED PLATE UNDER BENDING AND SHEAR STRESS
}

\author{
Kikuo IKARASHI* and Yoshihiro YANAGISHITA** \\ * Assoc. Prof., Dept. of Architecture and Building Engineering, Tokyo Institute of Technology, Dr. Eng. \\ ** Graduate Student, Graduate School, Tokyo Institute of Technology
}

From the economical point of view, H-shaped beams which have end stiffeners have been designed in steel frame structures. In this paper, the authors clarified the elastic buckling strength of stiffened plates under bending and shear stress by theoretical analysis using energy method. As prerequisite for the buckling analysis, stiffener line to the web plate element is supposed in consideration characteristic of flexural and torsional rigidity of stiffener.

First, authors confirmed the effect of torsional rigidity of stiffener to the elastic buckling strength of stiffened plates. At the same time, the effect of bending inclination to the elastic buckling strength is conducted along with consideration of bending and shear interaction and boundary condition of stiffened plates. Furthermore, authors considered the effect of torsional rigidity of stiffener to the buckling strength of stiffened plates. From the result of analysis, we revealed that the flexural rigidity of stiffener is the most important factor to the buckling strength of stiffened plate. Therefore, the approximation for optimum flexural rigidity of stiffener is derived for each boundary condition without torsional rigidity of stiffener. In addition, the relationship between effective stiffener shape and web width-thickness ratio is also investigated.

As a result, the following conclusions are reached.

1) The buckling strength of stiffened plate is considerably influenced by cross-sectional area ratio. The effective stiffener shape can be designed at small cross-sectional area ratio value when we consider the effect of constraint by flange and longitudinal stiffener.

2) Torsional rigidity of stiffener makes influence to angle deflection with stiffener attaching line. However, the effect of the torsional rigidity of stiffener to the buckling strength is too small and shows a negligible disagreement, regardless of the torsional rigidity of stiffener.

3) The ratio of flexural rigidity of stiffener also influences the buckling strength of stiffened plates. The buckling mode of stiffened plate which has high flexural rigidity stiffener is restricted, and the buckling mode has appeared on one side of the web plate separated by the stiffener.

4) The effective stiffener shapes can be designed by consideration of bending and shear interaction.

5) Optimum rigidity of stiffener under bending and shear stress has been approximated without torsional rigidity of stiffener. However, the stiffener satisfying this approximation cannot change buckling mode of stiffened plate, but the approximation is clarified from the point of buckling strength.

6) When the cross-sectional area ratio is greater than 0.2 , the effective stiffener shape can be designed. We clarified the relationship between effective stiffener shape and web plate shape for various $\eta \beta$ values.

(2014年 8 月 9 日原稿受理，2014年10月24日採用決定） 